\title{
Regional Determinants of Efficiency Growth of Small and Medium-Sized Enterprises. Evidence from Poland
}

\author{
Teresa Łuczka*, Paweł Przepióra ${ }^{* *}$
}

\begin{abstract}
SMEs sector plays a vital role in modern economies. Therefore, the interest in its functioning among economists is in fact quite natural. This article is a part of a current research on regional factors contributing to the development of enterprises in this category.

The first section examines earlier studies in this field conducted globally and in Poland. According to them, many elements enable the SME's development. It is not surprisingly that the specified set of pro-growth factors does not exists.

Next section describes the results of the author's own studies in the fields. These studies relate to regional factors contributing to the efficiency growth of micro, small and medium-sized enterprises in Poland. Data used in the study was collected from GUS ${ }^{[1]}$ and EUROSTAT and encompassed 16 provinces for the years 2003-2008. The model prepared included 11 independent variables on labor force, social mobility, living standard and R\&D policy. The authors would have gladly considered more than 11 explanatory variable, but the inaccessibility of such data made it impossible. In the next step, using GRETL software, equations of regression were defined. On this basis it was concluded that the most important factors contributing to efficiency growth of SMEs are the amount of spending on R\&D and the level of wages.

Keywords: small and medium-sized enterprises; factors of regional development; regions in Poland, business efficiency; entrepreneurship.
\end{abstract}

\section{Introduction}

Studies of broadly understood development of small and medium-sized enterprises have a long standing tradition in the literature of the subject. At their foundation lies a special role for enterprises of this size in the creation of basic macroeconomic values, such as GDP, employment or international exchange. Against this background attention is given to connections between the SME

\footnotetext{
* Teresa Łuczka, Professor, Poznan University of Technology, teresa.luczka@put.poznan.pl.

** Paweł Przepióra, Assistant Professor, Poznan University of Technology, pawel.przepiora@put.poznan.pl.

1 Central Statistical Office in Poland.
} 
sector and determinants of its development. Because of that, on the grounds of economic theory and practice factors are being sought which stimulate the development of small and medium-sized enterprises in both contexts: the economy as a whole and regionally. We must underline the mutual relationship between SMEs and region. On one side, small and medium-sized enterprises have influence on the development of the regions or countries (Valliere, Peterson, 2009), and on the other, particular regions create different conditions stimulating the development of entrepreneurship. For example according to some results, urban and rural areas differ from each other as potential environments for enterprises (Ritsilä, 1999).

Scientific studies were primarily focused on the role of SMEs in the economic development, possibilities of supporting innovation processes performed by economic entities of this category and on formulating effective economic policy on this background. Twenty years after the publishing of the famous Bolton report, C. Gray and J. Stanworth, evaluating the achievements of economics of small and medium-sized enterprises, drew attention to the change in approach to this notion. In studies on entrepreneurship, and particularly on possibilities of formulating effective policy for small and medium-sized enterprises sector, regional aspect started being considered (Gray, Stanworth, 1991). Ch. Karlsson and R. Dahlberg also emphasize that "one of the strongest, most important contexts for small business and entrepreneurship to emerge in recent years is region". They site explanation for this phenomenon mainly in the fact that at regional level there are certain facilitation in formulation and transmission of social capital (Karlsson, Dahlberg, 2003).

A region is also important from the perspective of creation and transformation of knowledge. "While it spills over across the firms and workers of a region, such regional spillovers tend to be localized; thus accessing and participating in knowledge requires geographic proximity. Small-firm networks, clusters, and linkages are organizational structures that have emerged in an effort to take advantage of the region" (Karlsson, Dahlberg, 2003). Important from the perspective of significance of a region and development of small and medium-sized enterprises is the approach presented within the New Economic Geography trend, according to which the key significance in the studies undertaken is played by such values as: potential market, transaction costs, internal and external economies of scale and strengthening development processes in the region, which provide new impulses for entrepreneurship like the development of small and medium-sized enterprises and contribute to the creation of clusters. The studies of these values are at the same time a starting point in formulation of effective state and local government policy for development of enterprises of this size and creation of clusters. 


\section{Regional determinants of development of small and medium-sized enterprises}

\section{Results of studies conducted worldwide}

A strength of a region consists of many factors, mainly connected with entrepreneurial climate, in the broad sense. In studies conducted in this field by the Rabobank in Holland, the following factors were analyzed: firm dynamics, SMEs sector dynamic, export orientation, willingness to invest instead of entrepreneurial willingness, labor productivity, investment in transport infrastructure, SMEs' R\&D expenditure and knowledge. The authors also cited many interesting research results, particularly from the area of broadly understood human resources. For example, a higher level of business activity was observed in many peripheral regions than in more economically developed region of Holland. This unexpected findings may be a result of 'congestion in business' arising from high competition, tougher barriers to entry, monopolistic position on some entities and a greater difficulty to be innovative (Naudé, Gries, Wood, Meintjies 2008). It was also noted that two out of three new firms are founded by one owner. The authors' of Rabobank research devoted particular attention to three other indexes, such as: education level, labor cost and job density, which for its particularly high level in large agglomerations is described as agglomeration effect. (Pellenbarg, van Steen, 2007).

In studies on the determinants of entrepreneurship, and especially on the conditions of creation of new firms in Great Britain, a number of additional factors were chosen and studied. It was found that regional factors affect both the creation process of new firms and their survival. Very important, from a research perspective are: population growth so far, high percentage share in the population of people with high managerial and vocational skills, urban concentration, household wealth, demand.

Several interesting regularities were also indicated, such as:

- new service companies arise in the proximity of large enterprises, and new production companies are located near small business.

- funds and programs supporting small and medium-sized enterprises decrease the number of bankruptcies,

- state programs for the SMEs sector are less significant in their creation than in increasing their survival rate. (Keeble, Walker, 1994).

Further results of the research conducted by M. Hart and S. McQuinnes on the factors impacting the development of small and medium-sized enterprises in Great Britain unequivocally indicated the role of government-funding, regional financing of enterprises of this size, particularly in regard to survival and death rate. Moreover, the SMEs using the Local Enterprises Development Unit (LEDU) support grow faster than others. A positive influence of urban region on SMEs location was also noticed, due to the access to entrepreneurship incubators (Hart, McQuiness, 2003). 
The literature on the subject includes three different approaches in research on the relationship between entrepreneurship growth in a region and an increase of a number of new workplaces. First of all it illustrates that pro-entrepreneurial attitudes result in creation of new enterprises, which automatically create new workplaces. Secondly, it is noted that new firms modify the level of competitiveness, forcing the existing firms to improve their to date competitive advantage. Furthermore, new enterprises are the source of innovation and consequently contribute to long-term economic growth.

Of interest, at least from a local differentiation perspective, are the results of the research from Lithuania, which point out that despite differences between particular regions in regard to population density, convergence was observed between GDP per capita and indexes characterizing SMEs. Additionally, an obvious correlation was observed between the decline of employment in agriculture and the increase of the SMEs sector. A clear differentiation between regions was also present in regard to the share of a particular region's export, import and direct investments. In conclusion, the authors emphasize that "The accomplished analysis explores an interregional contradictions increase which leads to uneven development of territories. Due to this, regional policy implemented by the state must pay attention to peculiarities of their development. It is clear enough that not separate, but a whole complex of means are necessary to enhance security of sustainability of development in Lithuanian regions. In decreasing inter-regional contradictions a special role may be played by purposeful support provided to export by the state that would help to diversity its marketable structure and extend assortment of imported ready production" (Bernatonyte, Vilke, Volochovic, 2009).

In research on the influence of regional factors on the start-up ratio conducted in Japan, the following measures were used: demand factors and costs (population growth rate, average wage in the manufacturing sector), human resources (unemployment ratio, the ratio of university graduates, ratio of employment in professional and technical occupations), financing (the ratio of householders as possibility of the start-up financing), industry agglomeration (density of establishments, proportions of manufacturing plants) and industry structure. Moreover, the researchers analyzed the average business size, the access to express stations, highway interchanges and the role of the public sector expressed as local servants to the populations. The results of conducted studies show strong positive influence of demand factors, human resources, effects of industry agglomeration, effect of average business size and traffic access on the start-up processes. A negative influence on this process was attributed to costs and householder ratio. As underlined by the authors, "These results give emphasis to the importance of the local accumulation of qualified human resources as supporting factor of start-up activities" (Okamuro, Kobayashi, 2006). This is reflected, among others, in positive correlation between the 
increasing number of start-ups in regions characterized by a larger share of higher education workers and higher employment in professional and technical occupations. There is also a positive correlation between the number of new enterprises and the number of real estate owners, because housing's ownership can be a good collateral and safety net for the founders. The smallest enterprises are created the fastest (Okamuro, Kobayashi, 2006).

In their research, $\mathrm{H}$. Westlund $\mathrm{i}$ R. Bolton assumed that entrepreneurship remains in close association with social capital; they also took into consideration the New Economic Geography approach, according to which in a region wage surplus is created beside producer and customer surplus (Westlund, Bolton, 2003). Similarly, as resulting from the study of S.Y. Lee, R. Florida and Z. Acs, special significance for creation and development of small and medium-sized enterprises should be sought for in social characteristics, and particularly in the influence of human capital and social diversity on entrepreneurship: "the results suggested, that one needs to pay attention to the social habitat of a region to boot a regional entrepreneurial dynamics" (Lee, Florida, Acs, 2004). It is being underlined that the more diverse regions try to attract more creative human capital by lowering the entry barriers, which ultimately results in business creativity.

A special type of the region - entrepreneurship relation occurs in periphery regions, less developed and unfavorable in terms of conditions for creating and running a business. Studies conducted by P. Vaessen and D. E. Keeble enabled them to formulate the following conclusions. „First, small business growth is possible under different territorial conditions, including different levels of competition and market between regions and differences in the occupational and skill structure of labor market. Secondly, many SMEs do not remain passive towards external pressures and constraints imposed by their regional environment. Instead, enterprises in peripheral regions may actively and even successfully work to develop strategies to overcome these constrains. Those firms success may acquire so much business expertise and market intelligence that they can even outstrip their counterparts in more favorable, resource-rich environments. In this way an initial location disadvantage may ultimately benefit rather than inhibit company growth and performance" (Vaessen, Keeble, 1995).

S. Venkataraman, in the study of changes in a region induced by entrepreneurship, emphasizes that in many scientific descriptions major attention is paid to tangible elements, such as: legal regulations, capital market, modern system of transport and communication (Venkataraman, 2004). These features are highlighted by the author as particularly important, as they - according to Schumpeter's approach - enable the enterprise to function in the region, and create conditions for techno-entrepreneurship development. The author also emphasizes the importance of intangible elements, particularly in the regions of developing countries, however these remarks may also be used in less developed 
regions of transforming countries. „Many developing regions are characterized by cultures that celebrate and depend on tradition. The most talented people are directed into position in which they are not rewarded for making bold bets. As a result, unconventional ideas, companies, projects, and products do not emerge. People who become entrepreneurs under these circumstances do so as a last resort. They may be unemployed, underemployed or handicapped, and their efforts generally result in low-quality enterprises". Such conditions, where venture capitals or risk capital are not interested in investing in such regions, and government programs do not additionally support this kind of entrepreneurship, consolidate a traditional structure, low business culture and ultimately low level of region's wealth. And people with innovative ideas emigrate to developed knowledge centers with universities. In order to retain them in the region and undertake the effort of its transformation by supporting technopreneurial activity, S. Venkataraman suggests such intangibles:

- local points capable of producing novel ideas: access to institutions that produce new knowledge,

- the need for right role model,

- the need for informal forums of entrepreneurship as well as the need for region-specific ideas to be created, access to entrepreneurial education and experience,

- the need for safety nets and the culture of accepting failure,

- the need for gateway cities to large markets for their products and services,

- the needs for executive leadership.

Similar conclusions with regard to possibilities of creation of various forms of information exchange forums and local leaders were formulated by economists studying this problem in a chosen region of Greece. They underline the significance of regional information centers, discussion forums and training programs, diffusion and creation of knowledge in equalizing the opportunities of particular regions and conditions of entrepreneurship functioning (Dimitriadis, Simpson, Andronikidis, 2005).

\section{Results of studies conducted in Poland}

Literature on the subject distinguishes many relationships between the region and entrepreneurship. Measuring these relationships on a local level, six groups of determinants can be distinguished (Krajewski, Śliwa, 2004):

- morphological,

- demographic,

- economic,

- organizational,

- structural,

- relational. 
Morphological determinants are connected with a size of a region, location, climate conditions, surface terrain, water and soil conditions, and demographic determinants refer to the characteristics of broadly understood human capital: population size and structure, including the division based on qualification, mobility inclination. Economic determinants - generally speaking - are related to the level of economic development; particular role of the possibility to gain external capital by small and medium-sized enterprises is underlined. Under organizational determinants we understand the quality of a functioning of local authorities; structural and relational determinants refer to the entrepreneurship area: the former describe the level of adjustment of enterprises location to the resources and market, the latter characterize the network of internal and external connections between particular participants of economic space (Krajewski, śliwa, 2004).

K. Safin, in turn, distinguishes three groups of determinants of entrepreneurial development: personality of the small and medium-sized enterprises owner, mesoeconomic and macroeconomic conditions. Among local determinants he lists: location, society education, active attitude of local society, local authorities ability to rationally formulate plans. (Safin, 2005).

The most detailed and valuable research on relationship between characteristics of a region and entrepreneurship in Polish literature was conducted by K. Wach. Considering the results of analysis made in the Małopolska and Śląsk regions in 109 small and medium-sized enterprises and in 150 communes, the authors characterized regional frameworks, which determine the conditions of creation and development of this size of enterprises (Wach, 2007). Such 16 factors were taken into account as:

- B2B services,

- business rent prices,

- closeness to/from co-operants,

- closeness to/from sales market,

- closeness to/from suppliers,

- commercial financial support,

- image of the region,

- IT infrastructure,

- living standard of local community,

- local policy in favor of SMEs,

- public financial support,

- regional business associations,

- regional business support centers,

- regional labor resources,

- supply of business offices,

- transport and physical infrastructure. 
The author, by querying entrepreneurs and local authorities, revealed certain differences in perception of pro-development factors among these two groups. According to entrepreneurs, the most important factors in this regard include IT infrastructure and the proximity of sales market and suppliers. Commune's authorities believe that most important stimuli of entrepreneurship are also sales market proximity, quality of local policy in favor of SMEs and image of the region. In an entrepreneurs opinion the least significant factor for their development are public financial support, local policy towards business and commercial financial support. In these fields local authorities express similar judgment. They are convinced that commercial financial support, public financial support and business rental rates are irrelevant for business success.

In studies of relationships between the region and entrepreneurship, K. Wach emphasized not only the factors supporting this process but also its barriers. And thus, the most important regional barriers to SMEs development include: inefficient public financial support, local policy in favor of SMEs and commercial financial. Entrepreneurs additionally believe that their development is unlikely to be blocked by supply of business offices, IT infrastructure and proximity to cooperants. As for communes authorities, the most burdensome are insufficient commercial and public financial support. Business rental rates can also be perceived as high burden. Very significant differences in perception of most important barriers by local authorities and business entities occur in regard to local policy in favor of SMEs. In communes, this barrier took the 14th place on the list, while for entrepreneurs it ranks as second most important obstacle. Other irrelevant barriers in communes opinion are regional labor resources and image of the region.

\section{Regional determinants of development of small and medium-sized enterprises in Poland - empirical studies}

The scope of research suggested by the authors of this article is slightly different than proposals of authors cited earlier. We decided to analyze the determinants of SME sector's development of efficiency, dividing nationwide data into provinces. The necessary data was collected from GUS (Central Statistical Office in Poland) and EUROSTAT. Data used in panel studies covered the years 2003-2008. In its initial form, the panel encompassed 16 provinces, 3 dependent variables and 11 explanatory variables. Methodology of econometrics recommends including in the initial model the widest possible set of economic variables, which helps explain the behavior of dependent variable. Further, with the use of the econometric model, an attempt was made to evaluate the significance of regional factors in the development of micro, small and mediumsized enterprises. The classical least squares method was used. While using this method, it is necessary to define a set of hypotheses, which the econometric model is to confirm or reject (Górecki, 2010). A zero hypothesis is always 
formulated in such a manner, that a given explanatory variable has no influence on a response variable, and the alternative hypothesis means that this influence exists. The next stage was to define the equations of regression - a GRETL software was used - which is the base for interpretation of correlations between variables. In further stages of the model improvement, the set of explanatory variables was reduced.

The dynamics of enterprises' efficiency growth in particular categories was measured with the volume of revenues generated by the enterprise of a given category per one employee in thousands PLN. The parameters, which are dependent variables in the proposed models are presented in table 1.

Table 1. Dependent variable in estimated econometric models

\begin{tabular}{llcc}
\hline No. & \multicolumn{1}{c}{ Dependent variable } & $\begin{array}{c}\text { Revenues in average enterprise } \\
\text { in Poland per employee } \\
\text { [thousands PLN] }\end{array}$ \\
& & $\mathbf{2 0 0 3}$ & $\mathbf{2 0 0 8}$ \\
\hline 1 & dynamics of micro-enterprises development & 146,2 & 200,3 \\
2 & dynamics of small enterprises development & 315,2 & 388,5 \\
3 & dynamics of medium enterprises development & 285,8 & 412,2 \\
\hline
\end{tabular}

Source: Bank of regional data of GUS.

Independent variables used in these studies do not cover the entire scope of regional environmental factors presented in previous sections due to data inaccessibility. Among dependent variables, the representatives of the following areas are missing: financial support, local authorities initiatives, entrepreneurship infrastructure, B2B services and communication infrastructure or socio-psychological profile of entrepreneur. The model, however, includes the variables describing labor source (active people, wages, unemployment, tertiary education, HRST, LLL), social mobility (permanent and temporary migration), local living standard (disposable income) and indirectly referring to technology (R\&D expenditure). One of the factors, namely the volume of investments in enterprises, is a characteristic feature of enterprises themselves and not a category of a regional environmental type (table 2).

As a result of calculations made with the GRETL software, a series of numerous parameters of formulated econometric models was achieved. The most important of these, referring to a reduced number of most significant determinants, are presented in table 3. 
Table 2. Independent variables used in models

\begin{tabular}{|c|c|c|c|c|}
\hline \multirow{2}{*}{ Independent variable } & \multirow{2}{*}{ Short name } & \multirow{2}{*}{ Unit } & \multicolumn{2}{|c|}{ Average value in Poland in } \\
\hline & & & 2003 & 2008 \\
\hline $\begin{array}{l}\text { Percentage of society professionally } \\
\text { active aged } 24-65\end{array}$ & Active people & $\%$ & 44,4 & 44.6 \\
\hline Average gross wage & Wages & PLN & 2315 & 3158 \\
\hline $\begin{array}{l}\text { Average monthly income at a } \\
\text { disposal of one person }\end{array}$ & Disposable income & PLN & 683 & 1007 \\
\hline $\begin{array}{l}\text { Investments per employee in } \\
\text { enterprises }\end{array}$ & Investment & $\begin{array}{l}\text { thousands } \\
\text { PLN }\end{array}$ & 17,5 & 30.0 \\
\hline$R \& D$ expenditures per citizen in PLN & $R \& D$ expenditure & PLN & 119 & 202 \\
\hline Unemployment rate & Unemployment & $\%$ & 19.6 & 7.1 \\
\hline $\begin{array}{l}\text { Percentage of people studying at } \\
\text { levels 5-6 (ISCED 1997) }\end{array}$ & Tertiary education & $\%$ & 5.2 & 5.7 \\
\hline $\begin{array}{l}\text { Human Resources in Science and } \\
\text { Technology* as a population ratio }\end{array}$ & HRST & $\%$ & 16.6 & 21.4 \\
\hline $\begin{array}{l}\text { Long life learning as percentage of } \\
\text { age population from } 24-65\end{array}$ & LLL & $\%$ & 4.4 & 4.7 \\
\hline $\begin{array}{l}\text { Balance of permanent migration as a } \\
\text { percentage of entire population }\end{array}$ & $\begin{array}{l}\text { Permanent } \\
\text { migration }\end{array}$ & $\%$ & 0.036 & 0.039 \\
\hline Balance of temporary migration** & $\begin{array}{l}\text { Temporary } \\
\text { migration }\end{array}$ & $\%$ & $\begin{array}{l}\text { from }-0.76 \\
\text { to } 0.46\end{array}$ & $\begin{array}{l}\text { from }-0.51 \\
\text { to } 0.41\end{array}$ \\
\hline
\end{tabular}

* These resources are defined either by education or current profession. As for the education, HRST includes qualified citizens with at least higher education (ISCED 5-6), also unemployed and inactive, and those without higher education, but performing tasks requiring specialized or technical higher education. More information on this subject can be found, for example, in a document, Retrieved from: http://epp.eurostat.ec.europa.eu/cache/ITY_SDDS/Anne-xes/hrst_st_sm1_an1.pdf [21.11.2009].

** This line presents range of balances in a given year in all provinces in Poland.

Source: Bank of regional data of GUS and EUROSTAT.

All presented models are characterized by the empirical value of parameter $F$ much higher than critical value taken from tables of $\mathrm{F}$ distribution, which means that the hypothesis about insignificance of equations of regression should be rejected.

Similarly, the coefficient of determination R2 reaches an acceptable level in around $85 \%$ of the cases of small and medium-sized enterprises, and $68 \%$ of the micro enterprises. This indicates that in presented models, respectively $85 \%$ and $68 \%$ of variability of the response variable is described by total variability of all explanatory variables in a given model, and $15 \%$ or $32 \%$ respectively of variability of the dependent variable is unexplained.

Coefficients calculated in the first model, regarding microenterprises, assume reasonable values. Their interpretation leads to the conclusion, that revenue per one microenterprise's employee increase of 0.186 thousand PLN if the R\&D expenditures per citizen are increased by $1 \%$. On the other hand, we will encounter a decrease in revenue per employee of 2.11 thousand PLN if the unemployment rate increases by $1 \%$. An explanation of such result may be explained (although 
the model has not indicated it) in the decrease in demand caused by the decrease in the citizens' financial resources. This explanation seems reasonable, especially when considering the fact that microenterprises usually operate in local markets. A decrease of microenterprises development dynamics (of 1.78 thousand PLN in revenue per employee) is also recorded if the percentage of professionally active citizens increases by $1 \%$. The only explanation of such a state of affairs may be the fact that a greater number of professionally active people entails a greater number of workers, with a relatively constant turnover in the enterprises sector in this region. Revenue per one employee in microenterprises also decrease by 27.52 thousand PLN, if the balance of temporarily migration compared to the size of the entire population increases by $1 \%$, which means that the number of citizens leaving the region will increase. The change in revenue is notable, but we should remember that the balance of temporary migration did not exceed $0.76 \%$ in any of the provinces in the given period. Therefore a change of migration balance of $1 \%$ is rather improbable.

Table 3. Parameters of econometric models

\begin{tabular}{|c|c|c|c|c|c|}
\hline $\begin{array}{c}\text { Type of } \\
\text { enterprise }\end{array}$ & $\begin{array}{c}\text { Significant explanatory } \\
\text { variables }\end{array}$ & ratio & p-value & $\mathbf{R 2}$ & $\mathbf{F}$ \\
\hline \multirow{4}{*}{ Micro } & R\&D expenditure & 0.186 & $<0.00001$ & \multirow{4}{*}{0.683246} & \multirow{4}{*}{$\begin{array}{c}F(4.91)=49.07 \\
F 005=2.47\end{array}$} \\
\hline & Unemployment & -2.110 & $<0.00001$ & & \\
\hline & Active people & -1.782 & 0.00042 & & \\
\hline & Temporary migration & -27.523 & 0.00187 & & \\
\hline \multirow{5}{*}{ Small } & Active people & -4.013 & $<0.00001$ & & \multirow{5}{*}{$\begin{aligned} F(5.90) & =118.21 \\
F 005 & =2.32\end{aligned}$} \\
\hline & R\&D expenditure & 0.343 & $<0.00001$ & & \\
\hline & Wages & 0.049 & 0.01928 & 0.867859 & \\
\hline & Temporary migration & 82.926 & 0.02243 & & \\
\hline & HRST & 6.201 & 0.03508 & & \\
\hline \multirow{5}{*}{ Medium } & Wages & 0.243 & $<0.00001$ & & \multirow{5}{*}{$\begin{array}{c}F(5.90)=98.07 \\
F 005=2.32\end{array}$} \\
\hline & Temporary migration & -60.4516 & 0.00411 & & \\
\hline & R\&D expenditure & 0.262 & 0.00611 & 0.844924 & \\
\hline & Disposable income & -0.251 & 0.00949 & & \\
\hline & Tertiary education & 15.6317 & 0.02246 & & \\
\hline
\end{tabular}

Source: Own.

The model explaining the development dynamics of small enterprises shows several similarities to the model regarding microenterprises. Development dynamics of small business entities as in micro-entities, also depends on the research and development expenditures, percentage of professionally active citizens and temporary migration. In case of the first two factors, the direction of correlation between explanatory and dependent variables is the same, only 
the sensitivity of dependent variable to the fluctuation of explanatory variable in case of small enterprises is greater than in case of microenterprises. And so, the revenue per employee in small enterprises increases by 0.343 thousand PLN, if the research and development expenditures per citizen in the region increase by $1 \%$. Revenue per employee of small enterprises will decrease by 4.013 thousand PLN if the percentage of professionally active people increases by $1 \%$. It is hard to explain the fact that an increase of temporary migration balance of $1 \%$ causes an increase of revenue per employee in small enterprises by as much as 83 thousand PLN. The increase of efficiency dynamics of small enterprises is also influenced by wages and the amount of Human Resources in Science and Technology. In case of the first parameter, an increase of $1 \%$ causes an increase in revenue per employee in enterprises of this category of $49 \mathrm{PLN}$, and the increase of HRST share in population of $1 \%$ yields an increase of the development dynamics meter in small enterprises of 6.2 thousand PLN. Both these facts can easily be explained, as a wage increase in a region translates into an increase in demand, and the increase in the ratio of people connected with science and technology normally translates into an increase of margins in businesses. It is so, because usually in such condition the enterprises located in a given region tend to sell more sophisticated, innovative goods and services.

The last model describes medium-sized enterprises. Their development depends mainly on the wage level. Each time it grows by $1 \%$, the revenues per one employee increases by $243 \mathrm{PLN}$. The direction of influence of migration on economic entities in this category is the same as recorded in the case of microenterprises. Revenue per employee decrease when the balance of people leaving the region is positive. Each $1 \%$ increase in this balance causes a decrease in revenue per employee of 60.45 thousand PLN. A positive influence on the development of medium-sized enterprises is also recorded in the case of increases of expenditures on research and development and the percentage of people acquiring higher education. An increase of R\&D expenditures per citizen of $1 \%$, as well as the increase of a number of university students in a population of $1 \%$, causes an increase of revenue per employee in enterprises of 0.26 and 15.63 thousand PLN respectively. In case of medium-sized enterprises it is hard to explain however, why an increase of disposable income of one citizen should cause a decrease of revenue per employee in this category of enterprises (increase in disposable income of $1 \%$ causes a decrease of revenues per employee by 251 PLN).

The presented models outline an image of factors (those, which were studied) which most significantly affect the development of SMEs sector (table 4). This group should most of all include the amount of expenditures on research and development and the wage level in a region. The influence of migration on performance of micro, small and medium-sized enterprises was inconclusive. In case of the active people factor, there are no prerequisites to question its 
influence on changes of average revenue per employee. A larger number of professionally active people can in fact contribute to a decrease in value of measured dependent variable. We cannot state however, that minimizing the percentage of active people brings socio-economic benefits, which the model suggests. Other explanatory variables were significant only in individual models, therefore it was assumed that their influence on the development of the entire SMEs sector is weak.

Table 4. Most important factors influencing the efficiency development of SMEs sector

\begin{tabular}{lcl}
\hline $\begin{array}{c}\text { Explanatory } \\
\text { variable }\end{array}$ & $\begin{array}{c}\text { Number of } \\
\text { models in which } \\
\text { the variable was } \\
\text { significant }\end{array}$ & Unambiguity and direction of influence on response \\
variable
\end{tabular}

Source: Own.

The region, in which the expenditures on R\&D (the most important SMEs' growth factor) grew the fastest is Świętokrzyskie province (table 5). An increase of $624 \%$ is impressive, however, these expenditures in 2003 were extremely low - 10 PLN per citizen (Poland's average at that time was 119 PLN). In this case we are certainly encountering a low base effect. Very good results in this regard were also achieved by Zachodniopomorskie, Pomorskie and Podlaskie provinces. A decrease in dynamics of research and development expenditures was recorded in Lubuskie province. Generally poor results were also achieved by Kujawsko-Pomorskie, Opolskie and WarmińskoMazurskie provinces. 
Table 5. Dynamics of R\&D expenditures in particular provinces in years 2003-2008

\begin{tabular}{lcc}
\hline \multicolumn{1}{c}{ Province35 } & $\begin{array}{c}\text { Base level } \\
\text { [PLN per citizen] }\end{array}$ & $\begin{array}{c}\text { Increase in R\&D } \\
\text { expenditure [\%] }\end{array}$ \\
\hline Lubuskie & 33 & -15.2 \\
Kujawsko-Pomorskie & 49 & 27.8 \\
Opolskie & 27 & 44.8 \\
Warmińsko-Mazurskie & 37 & 52.4 \\
Podkarpackie & 55 & 53.6 \\
Łódzkie & 106 & 57.2 \\
Śląskie & 80 & 63.9 \\
Mazowieckie & 389 & 64.1 \\
Wielkopolskie & 107 & 68.2 \\
Małopolskie & 160 & 70.2 \\
Lubelskie & 63 & 76.2 \\
Dolnośląskie & 89 & 78.7 \\
Podlaskie & 32 & 95.9 \\
Pomorskie & 90 & 99.3 \\
Zachodniopomorskie & 34 & 117.4 \\
Świętokrzyskie & 10 & 624.0 \\
\hline
\end{tabular}

Source: Own preparation based on GUS data.

Considering the increase of wages (the second most important SME's development factor), first place in this summary belongs to Dolnośląskie, Pomorskie, Lubelskie and Opolskie provinces (table 6). The lowest dynamics of positive changes in the level of wages were recorded in Warmińsko-Mazurskie, Lubuskie, Podkarpackie and Mazowieckie provinces. It is worth noting, that differences in particular regions between the wage dynamics are lower than those regarding research and development expenditures. 
Table 6. Wages dynamics in particular voivodeships in years 2003-2008

\begin{tabular}{lcc}
\hline \multicolumn{1}{c}{ Province } & $\begin{array}{c}\text { Base level } \\
\text { [thousands PLN] }\end{array}$ & $\begin{array}{c}\text { Increase in R\&D } \\
\text { expenditure [\%] }\end{array}$ \\
\hline Warmińsko-Mazurskie & 2.00 & 30.6 \\
Lubuskie & 1.99 & 33.3 \\
Podkarpackie & 1.95 & 34.1 \\
Mazowieckie & 3.01 & 34.3 \\
Kujawsko-Pomorskie & 2.00 & 34.5 \\
Wielkopolskie & 2.13 & 34.7 \\
Zachodniopomorskie & 2.13 & 35.0 \\
tódzkie & 2.02 & 35.4 \\
Świętokrzyskie & 2.02 & 35.6 \\
Śląskie & 2.38 & 36.1 \\
Podlaskie & 2.04 & 36.6 \\
Małopolskie & 2.11 & 37.6 \\
Opolskie & 2.09 & 37.7 \\
Lubelskie & 2.00 & 38.9 \\
Pomorskie & 2.26 & 40.3 \\
Dolnośląskie & 2.23 & 40.4 \\
\hline
\end{tabular}

Source: Own preparation based on GUS data.

\section{Conclusions}

Regional diversification may significantly influence the efficiency development of small and medium-sized enterprises. Research in this regard is a starting point in the formulation of the right economic policy for a country. They may also indicate which of the dependent factors and in what conditions significantly contribute to the socio-economic development. Among the research results cited in this publication, the factors that most frequently influence the development of the SME sector are: physical infrastructure, financial support, business-tobusiness services, regional policy in favor of SMEs, well-qualified labor resources and finally knowledge and technology transfer.

Studies conducted by the authors were aiming at identifying the important regional environmental factors in Poland. A certain limitation in formulating the econometric model for this purpose occurred in form of lack of some statistical data and unquantifiable nature of some of regional environmental factors. The task was also impeded by the requirements necessary to create a reasonable model, namely the necessity to consider relatively long term series of variable. Nevertheless, the models regarding micro, small and mediumsized enterprises were created and their reliability is satisfactory. Based on these models a conclusion was made that the factor most strongly connected with the efficiency development of enterprises in all categories is research and development expenditures. The higher those expenditures are, the more dynamically the enterprises develop. Other determinants with unequivocal and directly proportional influence on the development of SME sector are: 
- wages,

- tertiary education ratio,

- number of Human Resources in Science and Technology,

An inversely proportional relation between SMEs' efficiency growth and factors conditioning it was noticed in the case of such variable:

- active people,

- unemployment,

- disposable income.

\section{References}

Bernatonyte, D., Vilke, R., Volochovic, A. (2009). Regional Peculiarities of Development of Lithuanian SME. Economics and Management, 14, 676-84.

Dimitriadis, N., Simpson, M., Andronikidis, A. (2005). Knowledge Diffusion in Localised Economies of SME's: The Role of Local Supporting Organisations.

Environment and Planning C: Government and Policy, 23 (6), 799-814.

Górecki, B. R. (2010). Ekonometria - podstawy teori i praktyki, Warszawa: Key

Text. (ang.) Econometrics - Basic theory and practice, Warsaw: Key Text.

Gray, C., Stanworth, J. (1991). Bolton 20 Years on: The Small Firm in the 1990s.

University of Illinois at Urbana-Champaign's Academy for Entrepreneurial Leadership Historical Research Reference in Entrepreneurship. http://ssrn. com/abstract=1496718.

Hart, M., McQuinness, S. (2003). Small Firm Growth in the UK Regions 1994-1997:

Towards an Explanatory Framework. Regional Studies, 37 (2), 109-12.

Karlsson, Ch., Dahlberg, R. (2003). Entrepreneurship, Firm Growth and Regional

Development in the New Economic Geography: Introduction. Small Business Economics, 21 (2), 73-6.

Kneble, D. E., Walker, S. (1994). New Firm, Small Firms, and Dead Firms: Spatial Patterns and Determinations in the United Kingdom. Regional Studies, 28 (4), 411-27.

Krajewski, K., Śliwa, J. (2004). Lokalna przedsiębiorczość w Polsce. Uwarunkowania rozwoju. Warszawa: Wydawnictwo Naukowe Wydziału Zarządzania Uniwersytetu Warszawskiego. (ang.) Local entrepreneurship in Poland. Conditions for development. Warsaw: Publishing House of Faculty of Management in University of Warsaw.

Lee, S. Y., Florida, R., Acs, Z. (2004). Creativity and Entrepreneurship: A Regional Analysis of New Firm Formation. Regional Studies, 38 (8), 879-91.

Naudé, W., Gries, T., Wood, E., Meintjies, A. (2008). Regional determinants of entrepreneurial start-ups in a developing country. Entrepreneurship \& Regional Development, 20 (2), 111-24.

Okamuro, H., Kobayashi, N. (2006). The Impact of Regional Factors on the Startup Ratio in Japan. Journal of Small Business Management, 44, 310-13. 
Pellenberg, P. H., van Steen, P. J. M. (2007). The Regional Business Climate in the Netherlands. Spatial Variations in Entrepreneurship, Labour Productivity, Infrastructure and Knowledge. Journal of Economic \& Social Geography, 5, 696-705.

Ritsilä, J. J. (1999). Regional differences in environments for enterprises, Entrepreneurship \& Regional Development, 11 (3), 187-202.

Safin, K. (2005). Uwarunkowania rozwoju przedsiębiorczości - próba systematyzacji. In Uwarunkowania przedsiębiorczości, ed. K. Jaremczuk. Tarnobrzeg: Państwowa Wyższa Szkoła Zawodowa. (ang.) Conditions for development of entrepreneurship - an attempt to systematize, In Determinants of entrepreneurship, ed. K. Jaremczuk. Tarnobrzeg: State Higher Vocational School.

Valliere, D., Peterson, R. (2009). Entrepreneurship and economic growth: Evidence from emerging and developed countries. Entrepreneurship \& Regional Development, 21 (5/6), 459-80.

Vessen, P., Keeble, D. E. (1995). Growth-Oriented in Unfavorable Regional Environments. Regional Studies, 29 (6), 489-505.

Venkataraman, S. (2004). Regional Transformation Through Entrepreneurship. Journal of Business Venturing, 19 (1), 153-67.

Wach, K. (2007). Regional Barriers and Stimuli of SMEs Development in Southern Poland, In Prace Naukowe Katedry Ekonomii i Zarzqdzania Przedsiębiorstwem. Vol. IV. Gdańsk: Politechnika Gdańska (ang.) Regional barriers and stimuli of SMEs development in Southern Poland, In Scientific Papers of the Department of Economics and Business Management. Vol. VI, 379-84. Gdańsk: Gdańsk University of Technology.

Westlund, H., Bolton, R. (2003). Local Social Capital and Entrepreneurship. Small Business Economics, 21 (3), 77-113.

\section{Abstract (in Polish)}

Sektor małych i średnich przedsiębiorstw odgrywa kluczowq role we współczesnej ekonomii. Nie dziwi zatem ciqgłe zainteresowanie ekonomistów uwarunkowaniami jego funkcjonowania. Ta publikacja wpisuje się w ciagle aktualny nurt analizy wpływu różnych czynników na rozwój podmiotów gospodarczych tej kategorii.

Pierwsza część publikacji prezentuje przeglqad dorobku nauki światowej i polskiej w omawianym obszarze.

$Z$ analizy literatury łatwo wywnioskować, że wiele czynników przyczynia się do rozwoju małych iśrednich przedsiębiorstw. Nie dziwi również fakt, że trudno znaleźć zbiór zmiennych, który $w$ równym stopniu, $w$ różnych państwach i regionach oddziałuje na wzrost sektora MSP.

W kolejnej części publikacji przedstawiono wyniki badań własnych autorów. W badaniach tych podjęto próbę wyznaczenia czynników prowzrostowych wychodzqu od zmiennych wartości wybranych parametrów w poszczególnych regionach. Posłużono się danymi 
publikowanymi przez GUS i EUROSTAT dotyczqcymi 16 województw za lata 2003-2008. Stworzono model wykorzystujqcy 11 zmiennych niezależnych charakteryzujqcych zasoby ludzkie, mobilność społeczeństwa, standard życia i nakłady na badania i rozwój. Skorzystanie $z$ większej ilości zmiennych uniemożliwiła ich niedostępność. Badajq̨c problematykę wykorzystano program GRETL, dzięki któremu określono równania regresji. Na tej podstawie stwierdzono, że najważniejszymi czynnikami przyczyniajqcymi się do rozwoju małych i średnich przedsiębiorstw jest wielkość nakładów na $B+R$ oraz poziom wynagrodzeń.

Słowa kluczowe: małe $i$ średnie przedsiębiorstwa, czynniki rozwoju regionalnego, regiony w Polsce, efektywność przedsiębiorstwa, przedsiębiorczość. 